\title{
連鋳鋳片の表面性状に及ぼす磁気圧力の 効果に関するモデル実験と理論解析
}

\author{
Model Experiment and Theoretical Analysis for the Effect of \\ Electromagnetic Pressure on Surface Quality of Continuous \\ Castings
}

Ikuhiro SUMI, Kensuke SASSA and Shigeo ASAI

\begin{abstract}
Synopsis :
Being aimed to improve the surface quality of a continuously cast steel, a new electromagnetic casting method is proposed where the high frequency magnetic field is imposed on the initial stage of solidification from the outside of a mold. The magnetic pressure induced by the magnetic field provides the solidification taking place under the soft contacting pressure of molten metal with the mold, so called soft contacting solidification. Molten tin was cast by imposing magnetic field with $1.75,3.75$ and $15.4 \mathrm{kHz}$ frequency in order to examine the applicability of the method to the cast of steel. It is found that this electromagnetic casting method has a potential to be applied to the cast of steel. The stronger intensity of magnetic field could provide the better surface quality of products in the way of reducing oscillation marks. However, the excess intensity of magnetic field caused the disturbance on meniscus inducing surface defects. The critical intensity of magnetic field at which the surface defects due to fluid disturbances at meniscus appeared increased with increasing the frequency of magnetic field. It is noticed that the effect of magnetic field on reduction of surface defects appears more significantly when mold oscillation was not applied than when the oscillation was applied.
\end{abstract}

Key words : electromagnetic processing of materials; electromagnetic metallurgy; application of high frequency magnetic field; solidification; continuous casting; surface quality; oscillation mark.

\section{1. 緒}

言

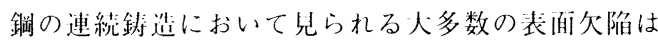
モールド内で牛ずる初期凝洞現象に划米することが知ら れている。この众陷は，表洦乎人れのための費用の増大， 歩留りの低下をもたらすのみならず，連鋳片を無乎入れ のまま㨁接川:延、程に移行させる㨁送左延の実現をも 妨げている。㝳，アルミニウムの分野に抢いては, まったくモールドを使用しない電磁鋳造法") (Electromagnetic Casting = EMC) の適用によって初期凝固過

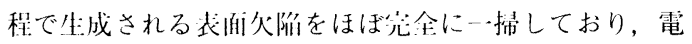
磁鋳造は尖用段階にある。そのため鉄鋼分野にあっても この $\mathrm{EMC}$ を適用することが长い間切望されてきたが, アルミニウムとの物性や生䍜性などの違いから，鋼への 直接的な適用は林難視されている.
ところが近年に童り，アルミニウムの分野に拉いて， モールドの外側より電磁気力を作用させ従来の EMCに 㠩敵する表面性状の鋳片が得られる CREM プロセス ${ }^{2)}$ の提案がなされた。このプロセスにあっては EMC とは 異なり，溶湯は電磁気力とモールドとの両者によって支 持されるが, 電磁気力によりモールドと溶湯との接触小: の低減が汹られているものと推論でき, 軟接触凝国と定 義された ${ }^{3)}$.この考えに基づけば鋼の連鋳においても表 面欠陷の極めて少ない鋳片の製造が叮能と期待できる. MIYOSHINO, TAKEUCHI ら ${ }^{4)}$ は $50 \mathrm{~Hz}$ の交流磁場中に水銀を いれた率器を設置し，水銀の谷器壁面压が電磁気力に よって減少することを確認している。また，すず一鈆令 金を用いたモデル尖験によって表面性状の優れた鋳片の 得られることも確認している。 また, 森, 中田らちも占も ルミニウムや鋼の鋳片表面性状改善にこの軟接触凝周が 
有効であることを認めている.

鋼の連続鋳造におけるオシレーションマークの生成は モールドと鋳片との間に強制的に流入，流出するフラッ クスの動压変化が主な原因であると考えられている ${ }^{6) 7}$. したがって，電磁気力によってモールドと鋳片の間隔の 搪大，あるいはメニスカス形状の茹定化がもたらされ動 压の低隇が汹られるならば，鋼の連続鋳造においても才 シレーションマークの軽減・消滅は夢ではないであろう。

以上の観点から, 本研究では, 鋼とほぼ必度の等しい すずを用いる連続鋳造のモデル実験系を構築し，楇波数 が $1.75 \mathrm{kHz} \sim 15.4 \mathrm{kHz}$ の磁場を黒鉛製のモールドの外 側より印加して，それが鋳片の表面性状に及ぼす効果を 種々の鋳造条件下で検討した。また，理論解析によって 鋳片回りの磁場分布を求め磁気庄: 打よび発熱量の計算を 行い, 実験結果の理解の一助とする。

\section{2. 実験}

\section{$2 \cdot 1$ 実験方法}

実験装置の概略汹を Fig. 1 に示す。モールドの外側 に 1 ターン ( $1.75 \mathrm{kHz}$ あるいは $3.75 \mathrm{kHz}$ の電源を用い る場合）または 4 ターン $(15.4 \mathrm{kHz}$ の電源を用いる場 合)のコイルを配して，コイル電流によって磁場の強 度を制御しつつ，高周波磁場を印加した。この周波数 帯で銅モールドを使用する場令には，磁場浸透媣さ $\delta$ $\left(=\sqrt{\frac{2}{\mu \omega \sigma}}\right)$ が非常に小さくなり, モールド内で磁場 の減就が起こり鋳片表百ままで磁場を浸透させることは難 しい。そのため, 本実験では電気伝導度の比較的小さい 黑鉛モールドを用いて磁場のモールド内減衰を極力抑え

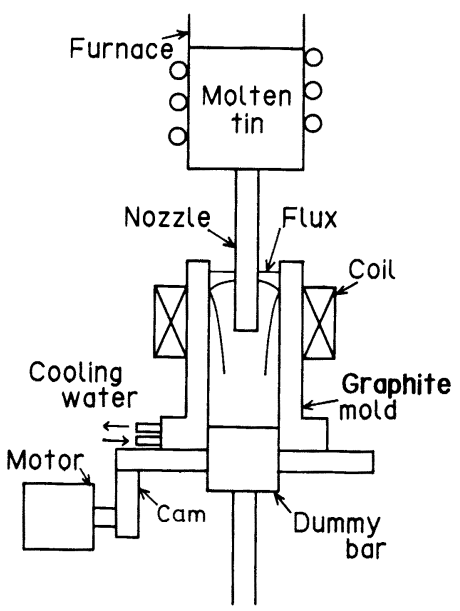

Fig. 1. Experimental apparatus.
Table 1. Experimental conditions.

\begin{tabular}{ll}
\hline Casting rate : & $2.3 \mathrm{~mm} / \mathrm{s}$ \\
Oscillation $\mid \begin{array}{l}\text { frequency : } \\
\text { stroke : }\end{array}$ & $1.1 \mathrm{~Hz}$ \\
Cooling water : & $3.0 \mathrm{~mm}$ \\
Super heat : & $50 \mathrm{~K}$ \\
Mold & $30 \mathrm{~mm}$ \\
\hline inner diameter : & $62 \mathrm{~mm}$ \\
\hline
\end{tabular}

るように夫した。試料には低融点 $\left(T_{m}=505 \mathrm{~K}\right)$ で，か つ鋼とほほ等しい密度 $\left(\rho=7200 \mathrm{~kg} / \mathrm{m}^{3}\right)$ を们するすず を用いた。モールド上部に設莦した为ですずを浴融し， 浸漬ノズルを介してモールド内 (内烽 $30 \mathrm{~mm}$ ) に注湯し た。溶晹がモールド内に $50 \mathrm{~mm}$ ほど溜まった時占で夕゙ ミ一バーを下方に移動して鋳造を開始した。その後，漸

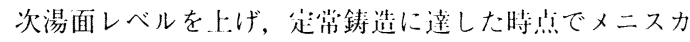
スの位置をコイル上端とほぼ、致させるように操作し た。な拉，フラックスの効果を見るためにシリコンオイ ルを擬似フラックスとして用いた。他の尖験条作を Table 1 に亦す.

\section{$2 \cdot 2$ 実験結果}

$2 \cdot 2 \cdot 1$ 鋳片の表百性状に及ぼす電磁㸚少の効果

鋳片の単位表旧積に加わる電磁気力（以下，磁気泣之 称する）が鋳片の表面性状におよぼす效果を印加磁場の 強度と成波数を変えて調查した。その際，コイル内部に 黒鉛モールドを配置した状態で磁場を発生させ，その時 のコイル中心の磁束密度をもって印加磁場の強度とし た。周波数 $3.75 \mathrm{kHz}$ で，印加磁場の溞度を 3 通りに変 えた場合に得られた鋳片の表酒性状をPhoto. 1 に尔す。 （a）は磁場を印加していない鋳片で，(b)，（c）はそれ ぞれ $0.04 \mathrm{~T} ， 0.05 \mathrm{~T}$ の磁場を印加して得られた鋳片で ある.（a）において観察される横縞状の欠陷すなわち才 シレーションマークは磁場の印加に伴い軽減され，0.04 T (Photo. 1（b)）でその効果が顕著となるが, $0.05 \mathrm{~T}$ (Photo. 1 (c)) になると, 鋳片表酒に活机の発牛が見ら れる.

オシレーションマークの生成原因は，亩にオシレー ションによるフラックスの動长:変化によると考えられて いる6)7).ここで，磁気压を印加することによって初期 凝固部におけるモールドと鋳片との接触屁の減少 (軟接

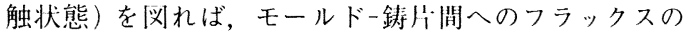
流人が容易になろう。また，晹面变動等の外乱に起因す るメ二スカスの不安定性をも高凬波磁界によって軽減す ることが叮能と考えられる ${ }^{8)}$. 以上の観点から, Photo. 1 (b) のオシレーションマークの軽減が説明できる. し かし, さらに磁気仕の増大を刚ると, 溶晹流動が活発化 し，メニスカス部での浴湯の乱れが観祭された。0.05 T の磁場を印加した場令（Photo. 1（c））に鋳片の表面性 

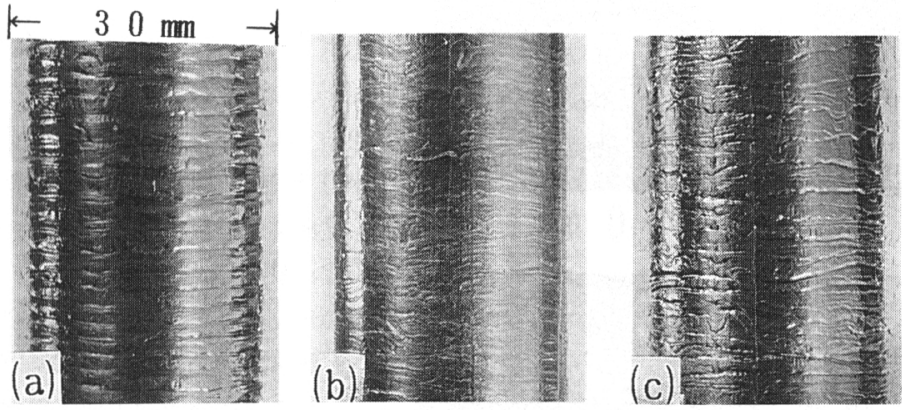

$\begin{array}{llll}\text { (a) } 0 \mathrm{~T} & \text { (b) } 0.04 \mathrm{~T} & \text { (c) } 0.05 \mathrm{~T}\end{array}$

Photo. 1. Surface aspects of cast billets $(3.75 \mathrm{kHz}:$ with oscillation).

状が悪化しているのは,この溶湯流動によるメニスカス 乱れが原因と考えられる。

$2 \cdot 2 \cdot 2$ 鋳片の表面性状に及ぼす磁場周波数の効果 印加磁場の周波数が高くなるほど, 磁場浸透深さ $\delta$ が減少し，溶湯の流動が抑制されることからメニスカス 形状は安定化する。そのため，印加磁場の周波数を増大 させることは，鋳片の表面性状に何らかの効果をもたら すものと期待できる.

周波数を $1.75 \mathrm{kHz}, \quad 15.4 \mathrm{kHz}$ の 2 通りに変化させ て得られた鋳片の表面性状を Photo. 2 に示す。これ らの周波数を用いて溶融すずの磁場浸透深さ $\delta(=$ $\sqrt{2 /(\mu \sigma \omega)})$ を求めると $\delta=8.3 \mathrm{~mm}(1.75 \mathrm{kHz})$ と $\delta=$ $2.8 \mathrm{~mm}(15.4 \mathrm{kHz})$ となる. 磁場を印加していない Photo. 1 (a) と比較していずれの周波数の場合において も，磁場の印加によってオシレーションマークが軽減さ れている. 特に周波数が $15.4 \mathrm{kHz}$ の場合では $0.015 \mathrm{~T}$ という小さな磁場でオシレーションマークの顕著な減衰 がみられ，0.02 T ではほとんど消滅している (Photo.2 (c), (d)). しかし, $1.75 \mathrm{kHz}$ の場合は, 磁束密度が $0.05 \mathrm{~T}$ で鋳片表面に乱机が認められる。これは， 3.75 kHz (Photo. 1 (c)) の時に見られたものと同じであり， メニスカス部の溶湯の乱れに起因するものと考元られ る. 一方, $15.4 \mathrm{kHz}$ の場合は鋳片表面の乱れは発生せず, $1.75 \mathrm{kHz} ， \quad 3.75 \mathrm{kHz}$ で得られた鋳片と比較すると表面 性状は極めて良好なものとなっている。

磁場を印加せずに鋳造した鋳片と周波数 $15.4 \mathrm{kHz}$ の 磁場を印加して鋳造した鋳片の水平断面と垂直断面のマ クロ組織写真を Photo. 3 に示す. 磁場を印加していな い（a）では鋳片表面から中心軸に向かってほぼ全体を 柱状晶が占めているが，磁場を印加した（b）には等軸 晶の部分が認められる。この原因としては, 印加磁場に よる溶融金属の㨽拌による結晶核の分散や、ジュール発

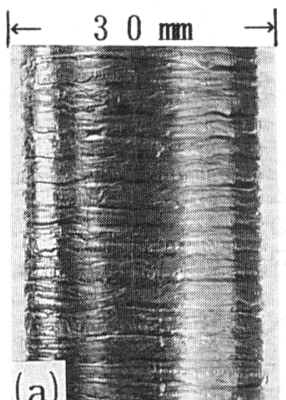

(a)
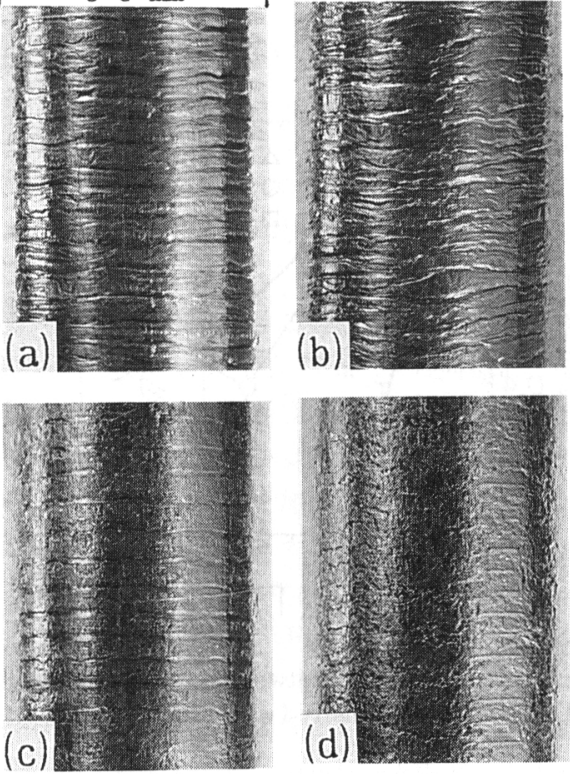

$\begin{array}{ll}\text { (a) } 0.04 \mathrm{~T}, 1.75 \mathrm{kHz} & \text { (b) } 0.05 \mathrm{~T}, 1.75 \mathrm{kHz}\end{array}$ $\begin{array}{ll}\text { (c) } 0.015 \mathrm{~T}, 15.4 \mathrm{kHz} & \text { (d) } 0.02 \mathrm{~T}, 15.4 \mathrm{kHz}\end{array}$

Photo. 2. Surface aspects of cast billets (with oscillation).

熱に起因する鋳片冷却速度の減少が考えられる。

次に，鋳片表面性状を定量化するため顕微鏡を用いて 表面粗度の測定を行った。ここでは，磁場を印加せずに 得られた鋳片の表面欠陥媣さ $D_{0}$ に対する測定された表 面欠陥深さ $D$ の比 $\left(D / D_{0}\right)$ をとり, これを表面粗度と した．Fig. 2 に磁束密度に対する表面粗度の変化をデー 夕のばらつきの幅と共に示す，表面粗度は印加磁場の增 加に伴い隇少し, 減少の度合いは周波数が高くなるほど 大きくなっている. 周波数が $15.4 \mathrm{kHz}$ の場合, $0.02 \mathrm{~T}$ に扔いて表面欠陥のほとんどない鋳片が得られた。周波 

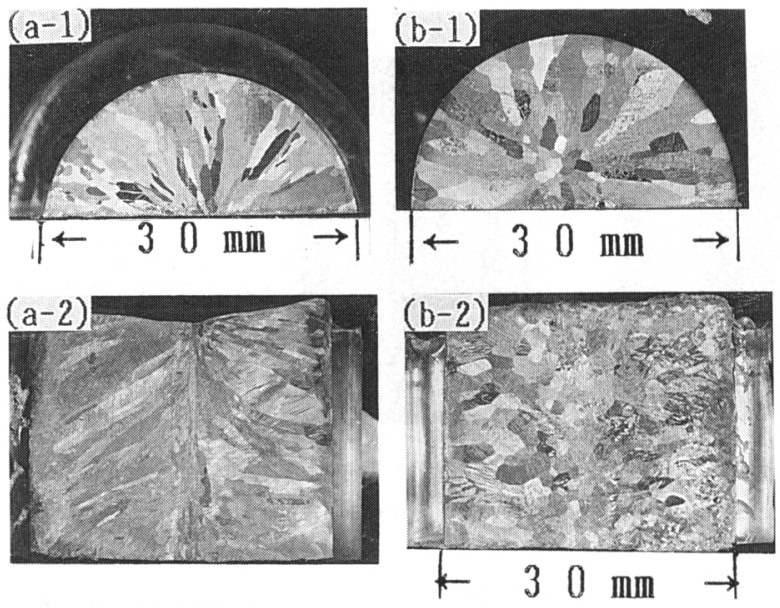

$\left(a^{-1}\right)$ Horizontal cross section and $\left(a^{-2}\right)$ vertical cross section : 0T

(b-1) Horizontal cross section and (b-2) vertical cross section : 0.02T

Photo. 3. Macrostructures of cast billets (15.4 kHz : with oscillation).

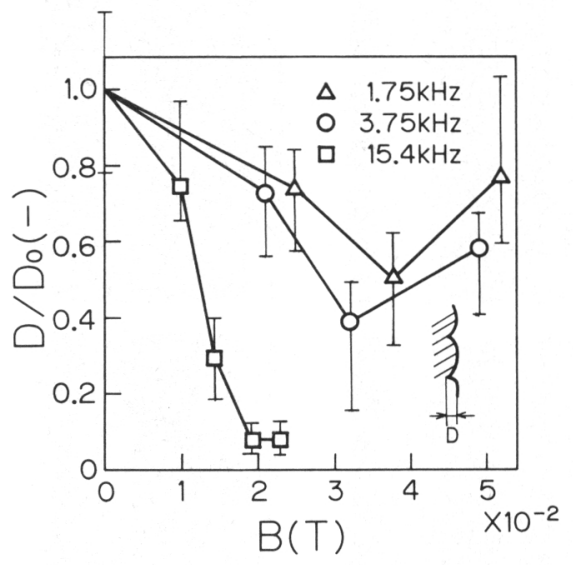

Fig. 2. Relationship between surface roughness and magnetic flux density (with oscillation).

数を $1.75 \mathrm{kHz}$ および $3.75 \mathrm{kHz}$ とした場合も, 磁束密 度の増加に伴い表面粗度は減少していく傾向にあるが, $0.05 \mathrm{~T}$ になると増加に転じている。この表面粗度の増 加はオシレーションマーク深さの増加を意味しているの ではなく，鋳造中におけるメニスカス乱れに起因するも のである.すなわち, 周波数が低い場合には, 印加磁場 の増加に伴いメニスカスの乱れにより欠陥が発生し表面 性状を悪化させるが, 周波数が高い場合には, たとえ磁 場強度が大きくなってもメニスカス部に乱れが生じない ため, オシレーションマークの軽減がなされたものと考 えられる.

\section{$2 \cdot 3$ モールド振動を行わない場合}

磁場の効果をより明確にするためオシレーションを加 えずに鋳造を行った．周波数 $3.75 \mathrm{kHz}$ の場合に得られ
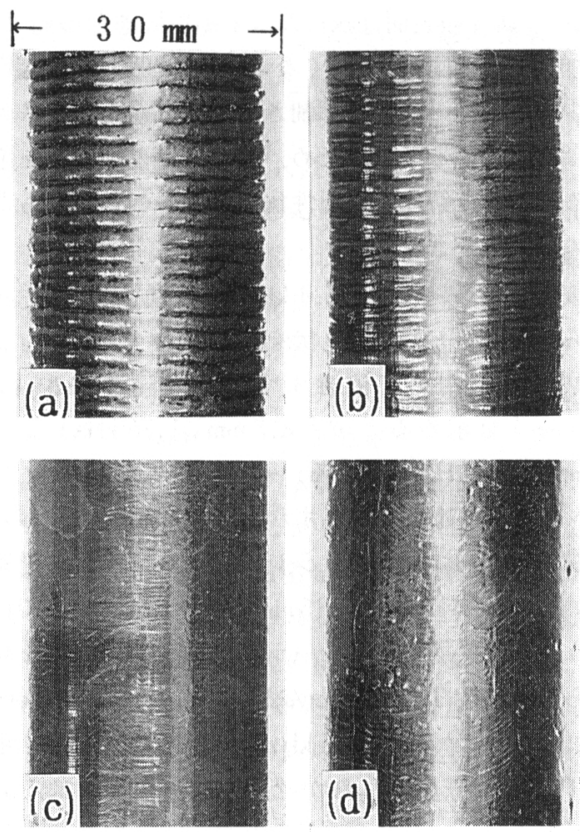

$\begin{array}{llll}\text { (a) } 0 \mathrm{~T} & \text { (b) } 0.02 \mathrm{~T} & \text { (c) } 0.05 \mathrm{~T} & \text { (d) } 0.07 \mathrm{~T}\end{array}$

Photo. 4. Surface aspects of cast billets (3.75 $\mathrm{kHz}$ : without oscillation).

た鋳片の表面性状をPhoto. 4 に示す。磁場を印加しな い場合には，オシレーションマークに非常によく似た表 面欠陥が生成されている (Photo. 4 (a)). なお，フラッ クスを使用しない鋳造ではこのようなオシレーション マークに類似な表面欠陷は認められなかったことから， この種の表面欠陥はフラックスに起因しているものと考 えられる.また,オシレーションを加えた場合と同様に, 
この場合にも磁束密度の増加に伴い鋳片の表面性状は改 善された. 表面欠宿の軽隇は印加磁場が $0.02 \mathrm{~T}$ (Photo. 4(b)) ですでに認められ，0.05 T (Photo. 4 (c)) にお いては極めて滑らかな鋳片が得られた。な㧍，メ二スカ スの乱れに起因する鋳片の表面欠陌は $0.07 \mathrm{~T}$ (Photo. 4 (d)) 付近から発生したが，オシレーションを加えた場 合に観察されたような激しい表面乱れは見られなかっ た。すなわち，鋳片の表面はオシレーションを加えた場 合 (Photo. 1) と比較して極めて滑らかであり，また， 比較的小さな磁束密度で表面欠陥の軽隇が始まり, 磁場 による表面性状改善効果はオシレーションを加えた場合 と比較してより顕著に現れている。

次に周波数 $1.75 \mathrm{kHz}, 15.4 \mathrm{kHz}$ の場合に得られた鋳 片をPhoto. 5 に示す. $3.75 \mathrm{kHz}$ では $0.02 \mathrm{~T}$ で表面欠 陥の軽滅が認められたが (Photo. 4 (b)), $1.75 \mathrm{kHz}$ の

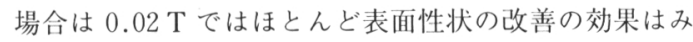
られない(Photo. 5 (a)). $0.05 \mathrm{~T}$ はかなり軽滅されて いるが (Photo. 5 (b)), 3.75 kHz の場合 (Photo. 4 (c)) と比較すると効果は小さい。一方, $15.4 \mathrm{kHz}$ の場合は, $0.01 \mathrm{~T}$ ですでに軽減効果がみられ (Photo. 5 (c)), $0.015 \mathrm{~T}$ で表面欠陥はほとんど消滅していることがわか る (Photo. 5 (d)).
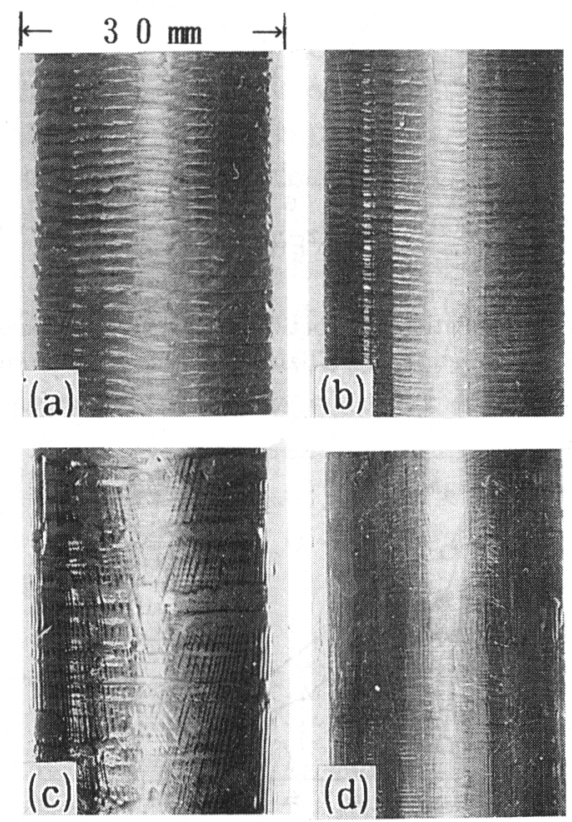

$\begin{array}{ll}\text { (a) } 0.02 \mathrm{~T}, 1.75 \mathrm{kHz} & \text { (b) } 0.05 \mathrm{~T}, 1.75 \mathrm{kHz}\end{array}$ $\begin{array}{ll}\text { (c) } 0.01 \mathrm{~T}, 15.4 \mathrm{kHz} & \text { (d) } 0.015 \mathrm{~T}, 15.4 \mathrm{kHz}\end{array}$

Photo. 5. Surface aspects of cast billets (without oscillation).

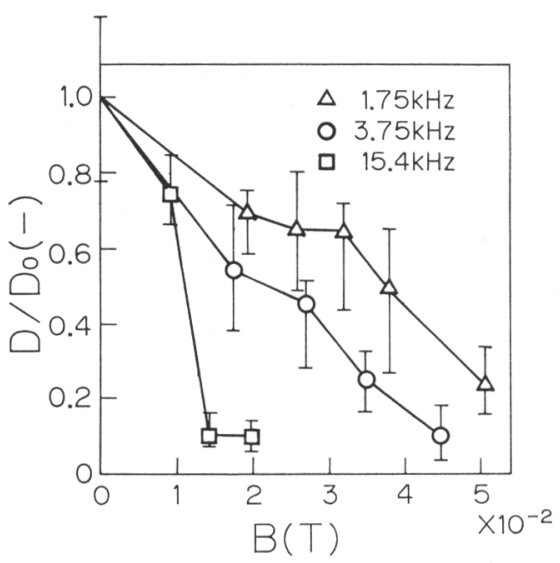

Fig. 3. Relationship between surface roughness and magnetic flux density (without oscillation).

このように，オシレーションを加えない場合において もオシレーションマークに類似する表面欠陥が生成さ れ，かつ，それが磁場の印加により軽減されていること がわかる.

Fig. 3 に磁束密度に対する表面粗度の変化を示す。才 シレーションを加えた場合 (Fig. 2) と同様に，印加磁 束密度の増加に伴い表面粗度は減少し, また，周波数が 高くなるにつれてその減少は顕著であることがわかる. さらに，オシレーションを加えた場合と異なり，いずれ の周波数においてもメ二スカス乱机に起因する表面粗度 の増加は見られないばかりか, 印加磁場の効果はオシ レーションを加えた場合 (Fig. 2) よりオシレーション を加えないもの（Fig. 3) の方がより顕著となっている. オシレーション印加の必要性とも考え合わせ，鋼の連鋳 に磁場印加を導入する際，本知見は考虑すべき重要な示 唆と考える。

\section{3. 考察}

\section{$3 \cdot 1$ 磁場の強度と周波数}

アンペールの法則を表す（1)式を, 電磁体積力（ロー レンッ力）を加える( 2 )式に代人すると（ 3 )式が得られ る.

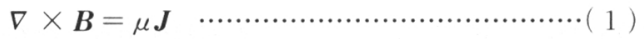

$$
\begin{aligned}
& \boldsymbol{F}=\boldsymbol{J} \times \boldsymbol{B} \\
& \boldsymbol{F}=\boldsymbol{J} \times \boldsymbol{B}=(1 / \mu) \cdot(\boldsymbol{\nabla} \times \boldsymbol{B}) \times \boldsymbol{B} \cdots \cdots \cdots \cdots(3)
\end{aligned}
$$

さらに, ベクトル演算の公式を用いて $(3)$ 式を変形する と(4)式となる ${ }^{9)}$.

$$
\boldsymbol{F}=\underset{f_{1}}{(\boldsymbol{B} \cdot \boldsymbol{\Delta}) \boldsymbol{B} / \mu-\boldsymbol{\Delta}\left(\boldsymbol{B}^{2} / 2 \mu\right)}
$$


右辺第一項 $f_{1}$ に回転 $(\nabla \times)$ を施した場合には必ずし も零になるとは限らないが, 第 2 項 $f_{2}$ は $\boldsymbol{B}^{2}$ の分布の いかんに関わらず，ベクトル公式に基づき回転を施すこ とによって常に零となる，すなわち， $f_{1}$ が回転力であ る可能性を有するのに対し， $f_{2}$ は常に非回転力である ことがわかる．前者は溶融部の流動を引き起こす駆動力 となり, 後者は表面張力ゃ静厈と均衡してメニスカス形 状を決定する. $f_{1}$ と $f_{2}$ の比は近似的に(5) 式で表され $ろ^{3)}$.

$$
\left|f_{1} / f_{2}\right| \simeq \delta / L
$$

ここで, $L$ は装㯰の代表長さで, $\delta$ は磁場浸透深さであ る.

周波数の増大に伴って $\delta\left(=\sqrt{\frac{2}{\mu \omega \sigma}}\right)$ は減少し, $\left|f_{1} / f_{2}\right|$ の値は小さくなり, 電磁気少はもっぱら非回 転力として働くようになる。 そのため, 周波数の増加に 伴い流動に起因するメニスカスの乱れは抑制されること になる。

一方，交流磁場印加の下で溶融金属表面に乱れが発生 した場合には（（）式に示される安定化压抽が発生する

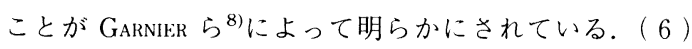
式から,この圧力は㸝波数の増加に伴って大きくなるこ とがわかる.

$$
P_{m}=\frac{B_{0}^{2} k z_{0}}{2 \mu} \cdot F(k \delta) \cos ^{2} \theta
$$

ここで,

$$
F(x)=\frac{\sqrt{\sqrt{\left(x^{4}+4\right)}+x^{2}}+(1-x) \sqrt{\sqrt{x^{4}+4}-x^{2}}}{\sqrt{2\left(x^{4}+4\right)}}
$$

である.モールド内で生ずる主要波数はモールド内径 2 $R$ を一波長とすると固有振動とすれば波数 $k$ は $k=$ $\pi / R$ となり， $k$ は定数とみなすことができる. その場令 には(6)式の安定化圧力は近似的に( 7 )式で表される比 例関係にある.

$$
P_{m} \propto B^{2} F(k \delta)
$$

一方, 磁気压の大きさは一般に $B^{2} / 4 \mu$ と表され, 洁 波数に依存しないかたちで用いられているが, 磁場浸透 深さ $\delta$ が融液の厚さ (軸対称系では半径 $a$ となる) に対 して十分小さいとはいえない本系のような場命にあって は周波数の依存性を考慮する必要性が生ずる.すなわち, 融液表面に実際に加わる磁気压は㖕波数の関数となり磁 気圧補正係数 $\Phi^{10)}$ を用いて $(8)$ 式のように書かれる.

$$
\begin{aligned}
& P=\Phi \frac{B_{0}^{2}}{2 \mu}, \quad \Phi=1-\frac{1}{b e r^{2} \alpha+b e i^{2} \alpha}, \\
& \alpha=\sqrt{2} \frac{a}{\delta} \ldots \ldots \ldots \ldots \ldots \ldots \ldots \ldots \ldots \ldots \ldots \ldots \ldots \ldots \ldots \ldots \ldots \ldots \ldots \ldots \ldots \ldots \ldots
\end{aligned}
$$

ここで, ber と bei は 0 次のケルビン関数である.
磁場の拡散力问に半無限に広がった融液の表酒安尘化 圧力として導出された（６），（７)式を有限長の融体に適 用するため，近似的ではあるが(8)式の磁気補正係数 $\Phi$ を使って( 7 )式の比例関係を( 9 )式で表す.

$$
P_{m} \propto \Phi B^{2} F(k \delta)
$$

(9)式を用いて Fig. 2 と Fig. 3 を整理しなおすと Fig. 4 と Fig. 5 となる. オシレーションを加えた場令 の結果である Fig. 4 のデータの内メニスカスの乱れに 起因するもの（印加磁場の増大に伴って表酒粗度が增大 に転じるもの) を除き， $1.75 \mathrm{kHz}, 3.75 \mathrm{kHz}$ のデータ は変数 $\Phi B^{2} F(k \delta)$ によってよく整理できることがわか る.しかし， $15.4 \mathrm{kHz}$ のデータはその限りではない. オシレーションを加えない場令 (Fig. 5) も $1.75 \mathrm{kHz}$ と $3.75 \mathrm{kHz}$ のデータに限ってはほぼ変数 $\Phi B^{2} F(k \delta)$ で整 理できるものの, $15.4 \mathrm{kHz}$ のデー夕は他の㸝波数のも のとは異なる傾问を示している。

Fig. 4, Fig. 5 を通して，1.75 kHz，3.75 kHz では表 面粗度が増加に転じるまでは，それらの変化はほぼ一致

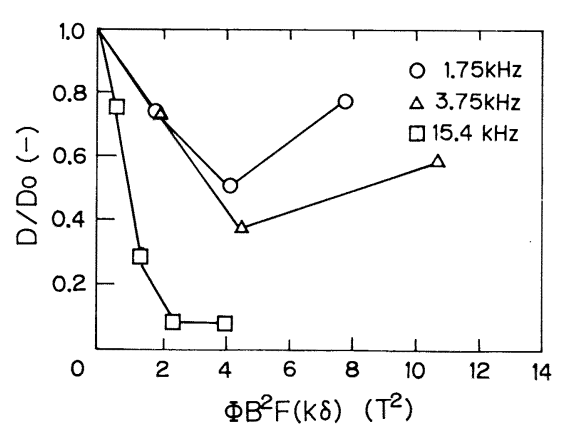

Fig. 4. Relationship between surface roughness and magnetic stabilizing parameter (with oscillation).

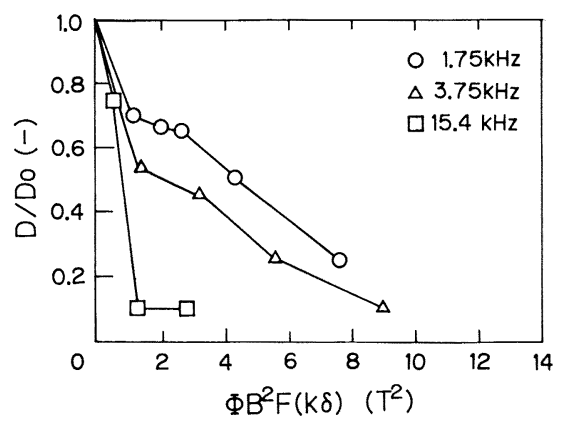

Fig. 5. Relationship between surface roughness and magnetic stabilizing parameter (without oscillation). 
しているが, $15.4 \mathrm{kHz}$ では $1.75 \mathrm{kHz}, 3.75 \mathrm{kHz}$ と比較 して，より大きな表面粗度の減少が見られる。これにつ いては後に述べるように洁波数の増大に伴う発熱量の増 大による凝固速度の変化, 濡れ性の変化等が考えられる が現時点では不明である。

\section{$3 \cdot 2$ 接触圧と発熱速度}

磁気ベクトルポテンシャル法を用いた 3 次元軸対称の 磁場解析を行い, 磁場印加に伴うモールドと溶湯間の接 触圧と発熱速度を計算した。

$3 \cdot 2 \cdot 1$ 基礎方程式

マクスウェルナ程式は次のように書き表される.

$\nabla \times \boldsymbol{E}=-\frac{\partial \boldsymbol{B}}{\partial t}$

$\nabla \times \boldsymbol{B}=\mu \boldsymbol{J}$

$\nabla \cdot \boldsymbol{B}=0$

ここで磁気べタトルポテンシャル $\boldsymbol{A}$ を(12)式で定義

すると(11)式は自動的に満足されることになる。

$\boldsymbol{B}=\boldsymbol{\nabla} \times \boldsymbol{A}$

次に,オームの法則は(13)式となる.

$\boldsymbol{J}=\sigma \boldsymbol{E}$

(1), (10)〜 (13)式を用いると磁気ベクトルポテンシャ ルについての基礎方程式が(14)式のように得られる ${ }^{11)}$.

$$
\nabla \times(\nu \nabla \times \boldsymbol{A})=\boldsymbol{J}_{0}-\sigma \frac{\partial \boldsymbol{A}}{\partial t}
$$

右辺第 1 項は強制電流によるものであり，第 2 項は誘 導電流項である。本実験系の境界条件の下で(14)式を解 いて $\boldsymbol{A}$ の分布が求まると, 次にそれを(12)式に代入し て $\boldsymbol{B}$ の分布が得られ, さらに(1)式を使って $\boldsymbol{J}$ の分布 が求まる。 また， $\boldsymbol{B}$ の值から $(3)$ 式を使って電磁体積 力 $\boldsymbol{F}$ が求まると, それを鋳片の半径方问に積分して磁 気压 $P$ が得られる。 さらに, 単位体積あたりのジュー ル発熱速度 $q$ は(15)式で求められる.

$$
q=J_{e}^{2} / \sigma
$$

(15)式の $q$ を体積積分すると, 磁場によって発生する 鋳片全体にわたる発熱速度 $Q$ を求めることができる.

\section{$3 \cdot 3$ 計算結果}

計算は有限要素法に基づいて名渥大学大型計算機 (M780-20) を用いて行った。兰角要素を用いて格子数 1500 , 要素数 3000 として行った計算時間は約 $15 \mathrm{~s}$ で あった、コイル電流 $1400 \mathrm{~A}$, 周波数 $3.75 \mathrm{kHz}$ の場合 の計算結果の一例をメニスカス近傍を拡大し磁気压（実 線), 溶湯静店：(破線）および接触庄：(一点鎖線）の分布 として Fig. 6 に亦す。ここで, 接触压とは磁気压と溶 湯静压との差であり，実際にモールドに加わる压力であ

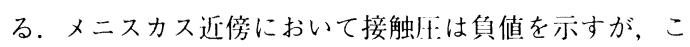

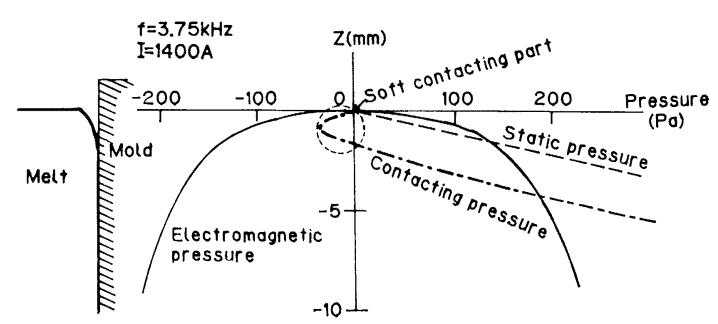

Fig. 6. Distributions of static, electromagnetic and contacting pressures.

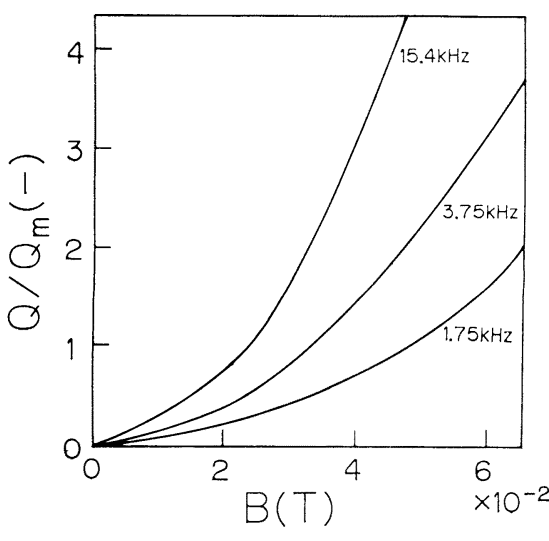

$Q_{m}=\rho_{v A \Delta H} \quad \rho:$ Density $\quad v$ : Casting rate $A$ : Sectional area $\Delta H$ : Latent heat

Fig. 7. Effects of the magnetic flux density and frequency on the joule heat induced in cast billets.

れはモールドと溶湯がこの領域では接触していないこと を意味している。なお，溶湯表面で接触压が頁僧を们す ることはありえずこのように負值をとった理由は単純 に接触压を溶湯静压から磁気压を引いたものとして計算 したために生じたものである。厳密にはメニスカス部の 形状変形を考慮した数值解析が必要となるが，ここでは そこまでの検討は行わなかった。メニスカス部では磁気 压力と溶湯静压の值が同程度であることから，笑際に モールド内面に作用する溶湯静压は大幅に減少し軟接触 状態の出現を予測させる.

鋳片に発生するジュール発熱速度 $Q$ と鋳片が放出す る凝固潜熱 $Q_{m}$ (一定) の比 $\left(Q / Q_{m}\right)$ を, 印加磁束密度 に対して示したのが Fig. 7 である。磁束密度の増加に 伴い発熱量は著しく増加し, 増加の割命は郕波数が高い ほど大きいことがわかる. 印加磁場に高い詰波数を選起 した場合，または磁束密度を増大させる場命はジュール 発熱が凝固潜熱を上回る $\left(Q / Q_{m}>1\right)$ ようになり，磁 気压の効果に加えて発熱の効果も現れる叮能性があると いえる。 
本実験において，鋳片の表面性状に変化が顕著に見え はじめる $\boldsymbol{B}$ の值は $1.75 \mathrm{kHz}$ では $3.8 \times 10^{-2} \mathrm{~T}, 3.65$ $\mathrm{kHz}$ では $3.2 \times 10^{-2} \mathrm{~T}, 15.4 \mathrm{kHz}$ では $2 \times 10^{-2} \mathrm{~T} て ゙$ あり，そのときの $Q / Q_{m}$ の值は Fig. 7 よりそれぞれ $0.7,0.92$ および 0.74 と読み取れる.すなおち, ジュー 儿発熱速度 $Q$ と凝固により放出される熱流量 $Q_{m}$ はほ ぼ等しい状態になっていることがわかる，そのため，磁 場印加によって得られたオシレーションマーク軽減効果 には磁気圧のみならずジュール発熱の効果も重畳されて いるものと考えられるが，本研究ではそれらを分離して 検討することはできなかった．ただし，ジュール発熱の 効果が無視できる低洁波の磁場を用いた他の研究者ら の結果とも考え合わせると，オシレーションマーク軽減 には磁気圧の効果が大きいものと推祭できる。

\section{4. 結論}

鋼の連鋳における表面性状の改善を目的として，モー ルドの外側より電磁気力を作用させるモデル実験をすず を用いて行い，次のことを明らかにした。

1)高周波磁場（1.75 kHz $15.4 \mathrm{kHz})$ を印加すること によって，オシレーションマーク等の表面欠陥を軽減す ることが叮能である。

2)印加磁場が過大な場合には，メニスカス部の乱れに 起因する表面欠陷が生じる。

3)印加磁場の周波数を高めることによってメニスカス の乱れの抑制と高周波磁界が有する波動抑制効果によ り，小さな磁場でも表面性状の改善を四ることが叮能と なる。

4)印加磁場による表面粗度の抑制効果はモールド・才 シレーションを行わない場命の方が行う場合より有効で ある。

最後に，本研究の遂行に当たり日本鉄鋼協会特定基礎 研究会「材料電磁プロセシング部会」および新日本製鉄 (株)，NKK，(株)神戸製鋼所より研究費の一部を補助 していただきました。ここに謝意を表します。また，示 唆に富む数々の助言をいただいた新日本製鉄(株)竹内栄 一氏，NKK 中田正之氏，(株)神戸製鋼所綾田研三氏に 厚く御礼申し上げます。さらに，デー夕の整理に当たっ ては李 廷挙氏 (中国大連理工大学) の手助けを受けま した。ここに，謝意を表します。

\section{記 号}

$\boldsymbol{A}:$ 磁場ベクトルポテンシャル $(\mathrm{Tm})$ $A$ : 断面積 $\left(\mathrm{m}^{2}\right)$ $a:$ 半径 $(\mathrm{m})$

$\boldsymbol{B}:$ 磁束密度 $(\mathrm{T})$

$B_{0}$ : 表面での磁束密度 $(\mathrm{T})$

ber, bei $: 0$ 次のケルビン関数

$D:$ 表面欠樎深さ $(\mathrm{m})$

$D_{0}:$ 無磁場下での表面欠際深さ $(\mathrm{m})$

$\boldsymbol{E}:$ 電界の強さ $(\mathrm{V} / \mathrm{m})$

$\boldsymbol{F}:$ 電磁体積力 $\left(\mathrm{N} / \mathrm{m}^{3}\right)$

$f:$ 周波数 $(\mathrm{Hz})$

$I:$ コイル電流 $(\mathrm{A})$

$k:$ 波数 $(1 / \mathrm{m})$

$\boldsymbol{J}:$ 電流密度 $\left(\mathrm{A} / \mathrm{m}^{2}\right)$

$J_{0}:$ 強制電流密度 $\left(\mathrm{A} / \mathrm{m}^{2}\right)$

$J_{e}:$ 誘導電流密度 $\left(\mathrm{A} / \mathrm{m}^{2}\right)$

$L:$ 代表長さ $(\mathrm{m})$

$L_{h}:$ 潜熱 $(\mathrm{J} / \mathrm{kg})$

$P:$ 磁気压 $(\mathrm{Pa})$

$P_{m}:$ 表面波動の妿走化压力 $(\mathrm{Pa})$

$Q$ : 発熱速度 $(W)$

$Q_{m}$ : 単位時間あたりに凝周に伴って放出される潜熱 (W)

$q:$ 単位体積あたりの発熱速度 $\left(\mathrm{W} / \mathrm{m}^{3}\right)$

$R:$ モールド内半径 $(\mathrm{m})$

$T_{m}:$ 融点 $(\mathrm{K})$

$t:$ 時間 $(\mathrm{s})$

$v:$ 鋳造速度 $(\mathrm{m} / \mathrm{s})$

$z_{0}:$ 乱れの振幅 $(\mathrm{m})$

$\delta:$ 磁場浸透深さ $(\mathrm{m})$

$\theta:$ 波数べクトルと磁束線のなす们度 $(\mathrm{rad})$

$\mu:$ 透磁率 $(\mathrm{H} / \mathrm{m})$

$\nu:$ 磁気抵抗率 $(=1 / \mu)(\mathrm{m} / \mathrm{H})$

$\rho:$ 密度 $\left(\mathrm{kg} / \mathrm{m}^{3}\right)$

$\sigma:$ 電気伀導率 $(\mathrm{S} / \mathrm{m})$

$\Phi:$ 磁気压補正係数 $(-)$

$\omega:$ 角培波数 $(\mathrm{rad} / \mathrm{s})$

\section{文献}

1 ) Ch. Vives and R. RicoU: Metall. Trans. B, 16 (1985), p. 377

2 ) Ch. Vivès and R. Ricou: Metall. Trans. B, 20 (1989), p. 623

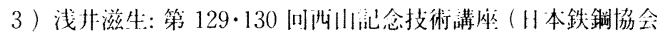
編) (1989), p. 51

4 ) I. Miyoshino, $E$. Takbuchi, $H$. Yano, $J$. Sakane, T. Sakikl and H. KAJIOKA: Trans. Iron Steel Inst. Jpn., 29 (1989), p. 1040

5 ) 森健太郎, 中田正之, 小松政美: 材料とプロセス, 2 (1989), p. 318

6 ) E. Takeuchi and J. K. Brimacombe: Metall. Trans. B, 15 (1984), p. 493

7 ) E. Takeuchi and J. K. BRimacombe: Metall. Trans. B, 16 (1985), p. 605

8 ) M. Garnier and R. Morfau: Metall. Appl. of Magnetohydrodynamics, London (1984), p. 211 [The Metals Society]

9 ) 浅井滋生: 鉄と鎆, 75 (1989), p. 32

10) J. D. Lavers: IEEE Trans. Ind. Appl., 17 (1981), p. 427

11) 中田高義, 高橋則雄: 電父江学の们限装素法 (1982), p. 13 [森北出版] 